community respiratory health survey. Health Qual Life Outcomes 2010;8:107 http://dx.doi.org/10.1186/1477-7525-8-107

3. WHO. Obesity: preventing and managing the global epidemic. Report of a WHO Consultation. WHO Technical Report Series 894. 2000.

4. WHO. Global database on Body Mass Index. [Website]; 2012 [updated 2012; cited]; Available from: http://apps.who.int/bmi/index.jsp.

5. Brown CD, Higgins M, Donato KA, et al. Body mass index and the prevalence of hypertension and dyslipidemia. Obesity research. [Research Support, U.S. Gov't, P.H.S.]. 2000;8(9):605-19.

6. Hubert HB, Feinleib M, McNamara PM, Castelli WP. Obesity as an independent risk factor for cardiovascular disease: a 26-year follow-up of participants in the Framingham Heart Study. Circulation 1983;67(5):968-77. http://dx.doi.org/ 10.1161/01.CIR.67.5.968

7. Salome CM, King GG, Berend N. Physiology of obesity and effects on lung function. J App/ Physiol 2010;108(1):206-11.

http://dx.doi.org/10.1152/ japplphysiol.00694.2009

8. Sin DD, Jones RL, Man SF. Obesity is a risk factor for dyspnea but not for airflow obstruction. Arch Intern Med 2002;162(13):1477-81.

http://dx.doi.org/10.1001/ archinte.162.13.1477

9. Collard P, Wilputte JY, Aubert G, Rodenstein DO, Frans A. The single-breath diffusing capacity for carbon monoxide in obstructive sleep apnea and obesity. Chest 1996;110(5):1189-93. http://dx.doi.org/10.1378/chest.110.5.1189

10. Ofir D, Laveneziana $P$, Webb KA, O'Donnell DE. Ventilatory and perceptual responses to cycle exercise in obese women. J App/ Physiol 2007;102(6):2217-26. http://dx.doi.org/10.1152/japplphysiol.00898.2006

11. Crummy F, Piper AJ, Naughton MT. Obesity and the lung: 2. Obesity and sleep- disordered breathing. Thorax 2008;63(8):738-46

http://dx.doi.org/ 10.1136/thx.2007.086843

12. Beuther DA, Sutherland ER. Overweight, obesity, and incident asthma: a metaanalysis of prospective epidemiologic studies. Am J Respir Crit Care Med 2007;175(7):661-6. http://dx.doi.org/10.1164/rccm.200611-17170C

13. Agusti A, Calverley PM, Celli B, et al. Characterisation of COPD heterogeneity in the ECLIPSE cohort. Respiratory research 2010;11:122.

14. Cecere LM, Littman AJ, Slatore CG, et al. Obesity and COPD: associated symptoms, health-related quality of life, and medication use. COPD 2011;8(4):275-84. http://dx.doi.org/10.3109/15412555.2011.586660

15. Ora J, Laveneziana P, Ofir D, Deesomchok A, Webb KA, O'Donnell DE. Combined Effects of Obesity and COPD on Dyspnea and Exercise Tolerance. Am J Respir Crit Care Med 2009;180:964-71.

16. Ramachandran K, McCusker C, Connors M, Zuwallack R, Lahiri B. The influence of obesity on pulmonary rehabilitation outcomes in patients with COPD. Chron Respir Dis 2008;5(4):205-9. http://dx.doi.org/10.1177/1479972308096711

17. Landbo C, Prescott E, Lange P, Vestbo J, Almdal TP. Prognostic value of nutritional status in chronic obstructive pulmonary disease. Am J Respir Crit Care Med 1999;160(6):1856-61

18. Franssen FM, O'Donnell DE, Goossens GH, Blaak EE, Schols AM. Obesity and the lung: 5. Obesity and COPD. Thorax 2008;63(12):1110-17. http://dx.doi.org/10.1136/thx.2007.086827

19. Zutler M, Singer JP, Omachi TA, et al. Relationship of obesity with respiratory symptoms and decreased functional capacity in adults without established COPD. Prim Care Respir J 2012;21(2):194-201. http://dx.doi.org/10.4104/ pcrj.2012.00028

\title{
education@pcrj: the launch of a new initiative for the PCRJ
}

\section{*Hilary Pinnock', Jaime Correia de Sousa}

a Senior Clinical Research Fellow, Allergy and Respiratory Research Group, Centre for Population Health Sciences, University of Edinburgh, UK

b Senior Lecturer, Community Health Department, Life and Health Sciences Research Institute (ICVS), School of Health Sciences, University of Minho, Portugal

*Correspondence: Dr Hilary Pinnock, Allergy and Respiratory Research Group, Centre for Population Health Sciences, The University of Edinburgh, Doorway 3, Medical School, Teviot Place, Edinburgh, EH8 9AG, UK

Tel: +44 (0)131650 8102 Fax: +44 (0)131650 9119

E-mails: hilary.pinnock@ed.ac.uk

jaimecsousa@gmail.com

The PCR has two declared aims in the context of primary care respiratory medicine: firstly, to be an 'authoritative setting for the publication of high quality internationally-relevant research'; and secondly, to 'inform and educate healthcare professionals worldwide of the research and service developments' in this field. ${ }^{1}$ This issue sees the launch of a new section in the Journal, education@pcrj, which will significantly promote the second of these two aims. As newly appointed Section Editors, we are delighted to accept the challenge laid down by the Editors-in-Chief, and look forward to delivering this core component of the PCRJ's editorial strategy. Our aim is to "satisfy the needs of "grass roots" primary care clinicians in implementing and applying research findings in practice'. ${ }^{1}$

Pre-empting this launch, journalwatch@pcrj first appeared in the March 2012 issue. ${ }^{2}$ Produced by the Editors-in-Chief, this will be a regular feature of education@pcrj from now on, enabling busy primary care clinicians to keep up-to-date with the latest research evidence from the top respiratory and general medical journals worldwide. Guideline summaries have always been a popular feature of the Journal|3,4 and these will appear in education@pcrj on a regular basis. Similarly, 'Evidence into practice' articles, short review articles of no more than 2000 words in length, will demonstrate how evidence from research can lead to changes in clinical practice.

The PCRJ has previously published Case-based learning ${ }^{5}$ articles similar to the traditional type of Case report, but in the future these will be incorporated into education@pcrj and re-formatted. The section in this issue on the importance of co-morbid rhinitis in patients with asthma demonstrates our new approach. It starts with a short clinical scenario - reflecting where we start as clinicians - and Scadding and Walker then provide a clinical overview of the management of the patient with co-morbid rhinitis and asthma together with an authoritative review of the evidence base. ${ }^{7}$ Exemplifying the fine balance between clinical practicalities and academic theory is the juxtaposition of a table summarising the academic evidence for a link between rhinitis and asthma with a practical illustration of how to use a nasal spray (which should be required reading for every primary care clinician and pharmacist... ). This review is then followed by two Perspectives - a new article category for the PCRJ: Osman Yusuf highlights the issues when 
working in primary care in a low- and middle-income country; and Ruth M cArthur provides some practical tips from her experience as a specialist nurse in a UK general practice. ${ }^{8}$

Plans are well advanced for the next few issues. The September issue will feature a clinical scenario of a 54 year-old man consulting about a long-standing cough, with Perspectives from primary and secondary care which explain how they would manage the problem within their national and health service contexts. In December we will focus on COPD, building on a clinical review of the approach to assessment and management advocated by the latest update of the GOLD guideline. ${ }^{9}$

However, this is only the beginning. Future ideas involve not just the hard copy version of the PCRJ, but also developing the facilities available on the Journal website (www.thepcrj.org). By asking authors to provide PowerPoint slides to accompany their articles, we hope to build an online library of topic-based resources which will draw on the rich source of relevant publications from the PCRJ as well as signpost the materials already available from the Primary Care Respiratory Society UK, the International Primary Care Respiratory Group, and other member organisations around the world.

Education needs to be a two-way process. At its simplest, we need your feedback, please. Is the concept working? Which of these ideas do you think will be most helpful? How can we further develop education@pcri? What are the topics you would like to see covered? We will continue to welcome submissions of Guideline summaries, 'Evidence into practice' articles, Case-based learning articles and Perspectives, all of which should stimulate the development of issue-based educational themes.

One of the PCRJ's aims is to encourage debate, and we are discussing ways in which we can enable more innovative interaction. Perhaps we should enable readers to respond to the published perspectives on clinical scenarios by submitting 'prompt perspectives' from their clinical practice which could be posted on an interactive section of the PCRJ website? Should we consider devising multiple choice questions to accompany articles? - perhaps arranging CME (Continuing Medical Education) accreditation. Should we commission Evidence into practice articles on a 'FAQ' format? An example of this would be papers in which authors provide evidence-based answers to a series of questions regarding the translation of guidelines into practice. Should we also invite them, when appropriate, to provide an education leaflet for patients about the review subject?
As the newly appointed editors of education@pcri, we are excited by the potential of this initiative. Please let us know what you think of our ideas - either by e-mailing us direct or via the PCRJ Editorial Office - and offer to be part of the initiative by suggesting ideas and submitting articles for the education section. Together we can inform and educate primary care health professionals and in so doing 'promote excellence in their care of patients with respiratory and respiratory-related allergic diseases.'

Conflicts of interest The authors declare that they have no conflicts of interest in relation to this article.

Funding HP is supported by a Primary Care Research Career Award from the Chief Scientist's Office, Scottish Government

Commissioned article; not externally peer-reviewed; accepted 12th May 2012; online 29th May 2012

(c) 2012 Primary Care Respiratory Society UK. All rights reserved http://dx.doi.org/10.4104/pcri.2012.00048

Prim Care Respir J 2012;21(2):133-4

\section{References}

1. Stephenson P, Sheikh A. A tribute to the past, and plans for the future: helping to drive top quality primary care respiratory disease management worldwide. Prim Care Respir J 2011;20(1):1-3. http://dx.doi.org/10.4104/pcrj.2011.00013

2. Journalwatch@pcrj. Prim Care Respir J 2012;21(1):115-17. http://dx.doi.org/10.4104/pcrj.2012.00014

3. Levy ML, Le Jeune I, Woodhead MA, Macfarlaned JT, Lim WS, on behalf of the British Thoracic Society Community Acquired Pneumonia in Adults Guideline Group. Primary care summary of the British Thoracic Society Guidelines for the management of community acquired pneumonia in adults: 2009 update. Prim Care Respir J 2010;19(1):21-7. http://dx.doi.org/10.4104/pcrj.2010.00014

4. Angier E, Willington J, Scadding G, Holmes S, Walker S. Management of allergic and non-allergic rhinitis: a primary care summary of the $\mathrm{BSACI}$ guideline. Prim Care Respir J 2010;19(3):217-22. http://dx.doi.org/10.4104/pcrj.2010.00044

5. Mir E, Shah A. Allergic bronchopulmonary aspergillosis in a patient with chronic obstructive pulmonary disease. Prim Care Respir J 2012;21(1):111-14 http://dx.doi.org/10.4104/pcrj.2012.00001

6. Scadding G, Walker S. Poor asthma control? - then look up the nose. The importance of co-morbid rhinitis in patients with asthma. Prim Care Respir J 2012; 21(2):222-8. http://dx.doi.org/10.4104/pcrj.2012.00035

7. Yusuf OM. Management of co-morbid allergic rhinitis and asthma in a low and middle income healthcare setting. Prim Care Respir J 2012;21(2):228-30. http://dx.doi.org/10.4104/pcrj.2012.00036

8. McArthur R. A practical approach to managing asthma and rhinitis. Prim Care Respir J 2012;21(2):230-32. http://dx.doi.org/10.4104/pcrj.2012.00037

9. Global Initiative for Chronic Obstructive Lung Disease (GOLD) Global Strategy for the diagnosis, management and prevention of chronic obstructive pulmonary disease: updated 2011. Available from http://www.goldcopd.com (accessed May 2012)

Available online at http://w w w.thepcrj.org 